\title{
ANALYZING EXPRESSIVE SPEECH ACTS OF THE MAIN CHARACTER IN THE JOKER MOVIE
}

\author{
Shevira Selsibilla ${ }^{1}$, Novitri $^{2}$, Erni $^{3}$ \\ 1,2,3 Universitas Riau, Pekanbaru, Indonesia \\ 1sheviraselsibilla13@gmail.com, ${ }^{2}$ novitri@lecturer.unri.ac.id, ${ }^{3}$ erni@lecturer.unri.ac.id
}

\begin{abstract}
This research aimed to find out the types of expressive speech acts and the context of the expressive speech acts uttered by the main character in the Joker movie. The design of the research was descriptive qualitative research. The data source was the Joker Movie directed by Todd Phillips. The movie was released in 2019 and its duration was about 1 hour 55 minutes. The data of this research were utterances included as expressive speech acts. The data were collected by watching, observing, and writing down the utterances indicated as expressive speech acts found in the movie. The data were analyzed by using formal and informal methods. The data were presented by using a table (Formal method) and description (Informal method). The contexts of the utterances were analyzed by using SPEAKING model. The results of the analysis showed that there were six classifications of expressive speech acts uttered by the main character in the Joker Movie. The total number of expressive speech acts found in the movie was 27 utterances covering 7 utterances of greeting, 6 utterances of agreeing, 5 utterances of thanking, 4 utterances of apologizing, 3 utterances of wishing, and 2 utterances of exclamation. The researcher found that the expressive speech act of greeting was the most frequently used by the main character. It showed that the main character liked to express his salutation when he met someone.
\end{abstract}

Keywords: analysis, expressive speech acts, joker movie

\section{ANALISIS TINDAK TUTUR EKSPRESIF TOKOH UTAMA DALAM FILM JOKER}

\begin{abstract}
ABSTRAK
Penelitian ini bertujuan untuk mengetahui jenis-jenis tindak tutur ekspresif dan konteks tindak tutur ekspresif yang diucapkan oleh tokoh utama dalam film Joker. Desain penelitian ini adalah penelitian deskriptif kualitatif. Sumber data adalah Film Joker yang disutradarai oleh Todd Phillips Film ini dirilis pada tahun 2019 dan durasinya sekitar 1 jam 55 menit. Data penelitian ini adalah ujaran-ujaran yang termasuk tindak tutur ekspresif. Pengumpulan data dilakukan dengan menonton, mengamati, dan menuliskan ujaran-ujaran yang diindikasikan sebagai tindak tutur ekspresif yang terdapat dalam film. Data dianalisis dengan menggunakan metode formal dan informal. Data disajikan dengan menggunakan tabel (metode formal) dan deskripsi (metode informal). Konteks ujaran dianalisis dengan menggunakan model SPEAKING. Hasil analisis menunjukkan bahwa terdapat enam klasifikasi tindak tutur ekspresif yang diucapkan oleh tokoh utama dalam Film Joker. Jumlah total tindak tutur ekspresif yang ditemukan dalam film adalah 27 ucapan yang meliputi 7 ucapan salam, 6 ucapan setuju, 5 ucapan terima kasih, 4 ucapan permintaan maaf, 3 ucapan berharap, dan 2 ucapan seru. Peneliti menemukan bahwa tindak tutur ekspresif sapaan adalah yang paling sering digunakan oleh tokoh utama. Hal ini menunjukkan bahwa tokoh utama suka mengucapkan salam ketika bertemu dengan seseorang.
\end{abstract}

Kata Kunci: analisis, tindak tutur ekspresif, film joker

\begin{tabular}{|c|c|c|}
\hline Submitted & Accepted & Published \\
\hline 02 September 2021 & 28 November 2021 & 24 Januari 2022 \\
\hline
\end{tabular}

\begin{tabular}{|l|c|l|}
\hline Citation & $:$ & Selsibilla, S., Novitri, N., \& Erni, E. (2021). Analyzing Expressive Speech Acts of the Main Character in the Joker Movie.
\end{tabular}
Jurnal PAJAR (Pendidikan dan Pengajaran), 6(1), 60-67. DOI : http://dx.doi.org/10.33578/pjr.v6i1.8549.

\section{INTRODUCTION}

Language is one of the crucial things in human life. Language is a system of creating words, sounds, movements used by human beings to communicate with others in daily life. This is the reason why language can't be separated from human life since people interface with each other by using language. In communication, people are able to exchange knowledge, opinions, wishes, and beliefs by using language. Additionally, people can use language to protest, thank, promise, ask, criticize, insult, and act.

According to Austin (1962), people can also act or do something by uttering words, and ask other people to do things through words. That is called speech act. The speech act theory is first delivered by Austin (1962) in his book How to Do 
Things With Words. He classifies the speech act into three parts; those are a locutionary act, illocutionary act, and perlocutionary act. Furthermore, the theory of speech act had been developed by American philosopher J.R. Searle (1969). He also divides five categories for speech acts; those are assertives, commissives, directives, expressives, and declarations.

An expressive speech act is one of the subdivisions of speech act that has the function to express what a speaker feels towards a certain situation via utterances. Searle (1979) states that expressive speech act means to express a speaker's psychological state in a certain condition. This kind of utterance has several functions, such as to express apologizing, thanking, congratulating, condoling, blaming, pardoning, welcoming, forgiving, wishing, and praising that related to the feelings of the speaker. Additionally, Norrick (1978) says that psychological state is related to emotions. He also classifies 9 types of expressive speech act such as apologizing, thanking, congratulating, condoling, deploring, lamenting, welcoming, forgiving, and boasting.

In a recent research, Guiraud (2011) defines expressive speech acts as public expressions of emotional states. She divides the emotional states into two types: basic emotions and complex emotions. Weigand (2010) also identifies the expressive speech act as emotive where it focuses on a speaker's emotional involvement. Emotives link to the speakers' emotional side, feelings, opinions, expecting back empathy and compassion. Several researches concern with classifying expressive come from both linguistic and psychological sources, especially the ones aimed at discovering about emotions in their studies such as Weigand (2010), Macagno (2010), Lindquist (2013), Ronan (2015), Aristidou (2015), and Reisha (2018). In conclusion, an expressive speech act tells about a speaker's feelings, attitudes and state of mind.

In this research, the researcher also discusses the context of expressive speech acts. Rusiana (2018) says in her research that speech act is the analysis of intended meaning of the spoken and written utterances. She also said that the important thing in a speech act is to understand the message of the speaker's utterance.
Similarly, Martinez (2010) states the listener can understand the message of the speaker's utterances by its context. Context means the situation or condition that is created and constructed in the activity of speaking and or when the utterance is produced.

Based on the explanation above, the researcher wants to find out the classifications of expressive speech acts uttered by the main character and its contexts in Joker movie. This study will answer the research questions "What are the expressive speech acts performed by the main character and what is the context?".

\section{REASERCH METHOD}

This study was descriptive qualitative research. Descriptive qualitative research is characterized by its aims which relate to understanding some aspect of social life and rather than numbers as data for analysis (Patton 2002). The data of this research are utterances which are classified as expressive speech act. The data was taken from a movie entitled "Joker" directed by Todd Philips. All the data sources were from the utterances or the dialogue produced by the main character in the movie that was indicated as expressive speech acts.

In this study, the researcher became the main instrument in analyzing the data because this research did not involve anyone else other than the researcher herself. The researcher collected the data and analyzed the data by watching and observing the movie, analyzing and classifying the type of expressive speech acts and its context produced by the main character in the movie "Joker" directed by Todd Philips. In analyzing the movie, the researcher also used some tools to help her such as laptop, notebook, and pen.

In collecting the data, the researcher used some steps. The steps used in collecting the data are as follows:

1. The researcher downloaded the movie "Joker".

2. The researcher watched the movie "Joker" with an English subtitle.

3. The researcher used a notebook and pen to collect all the utterances of expressive speech act found in the movie "Joker" 
4. The researcher classified all the utterances found in the movie "Joker" by giving some codes for each type of expressive speech acts.

The researcher also identifies the types of expressive speech act in the movie by giving some codes for each type of expressive speech acts to help the researcher in identifying the types of expressive speech act. The researcher uses these codes:

$\begin{array}{ll}\text { Th } & \text { : thanking } \\ \text { Gr } & \text { : greeting } \\ \text { Ap } & \text { : apologizing } \\ \text { Cr } & \text { : congratulating } \\ \text { Con } & \text { : condole } \\ \text { Ag } & : \text { agreement } \\ \text { Ws } & : \text { wishing } \\ \text { Lam } & : \text { lamentation } \\ \text { Exc } & \text { : exclamation }\end{array}$

In this research, the researcher also analyzed the contexts of expressive speech acts by using Dell Hymes'SPEAKING model. Hymes (1974) explains the SPEAKING model as a way to study how people talk and to analyze speech events. He intends to create a theory that can help researchers in studying language in specific contexts. SPEAKING stands for Setting, Participant, Ends, Act of sequence, Key, Instrument, Norms, and Genre.

The results of the analysis were presented by two methods; formal and informal methods by Sudaryanto (1993). Formal method means describing the result by using the table and informal method means presenting the findings by using verbal language and then gives some explanation based on the analysis of the data.

\section{RESULTS AND DISCUSSION}

The objective of this research is to find out the classifications of expressive speech acts uttered by the main character in Joker movie. There are 6 types of expressive speech acts that have been found by the researcher. They are greeting, apologize, exclamation, wishing, thanking, and agreement. There are 27 expressive utterances that have been found from the movie. The data are tabulated as follows:

Table 1. frequency of expressive speech acts

\begin{tabular}{llc}
\hline No. & Types of Expressive Speech Act & Frequency \\
\hline 1 & Greeting & 7 \\
2 & Apologizing & 4 \\
3 & Exclamation & 2 \\
4 & Wishing & 3 \\
5 & Thanking & 5 \\
6 & Agreement & 6 \\
& \multicolumn{2}{c}{ Total } \\
\hline
\end{tabular}

In Table 1 presents the six types of expressive speech acts that have been found by the researcher from the Joker movie. Those are greeting, apologizing, exclamation, wishing, thanking, and agreement. Based on the table above, there are 7 utterances of greeting, 4 utterances of apologizing, 2 utterances of exclamation, 3 utterance of wishing, 5 utterances of thanking, and
6 utterances of agreement. There are 27 utterances that has been found by the researcher that indicated as expressive speech acts. Based on the analysis table above, expresssive speech act of greeting was the most frequently performed by the main character. Furthermore, the contexts of the expressive speech acts are presented in tables as follow:

Table 2. Greeting

\begin{tabular}{llc}
\hline No & Greeting & The Context of Expressive Speech Acts \\
& Utterances
\end{tabular}




\begin{tabular}{|c|c|c|}
\hline 1 & Hi, Murray & $\begin{array}{l}\text { At night, in a talk show with Murray Franklin. He greets } \\
\text { Arthur and askes his name. Then, Arthur greets him back } \\
\text { and tells his name. He speaks politely. }\end{array}$ \\
\hline 2 & Hello, Hoyt & $\begin{array}{l}\text { In Arthur's boss office, Arthur greets his boss named hoyt } \\
\text { right after entering the office. He speaks politely. }\end{array}$ \\
\hline 3 & Oh, hey & $\begin{array}{l}\text { At Arthur's apartment. When, Arthur's neighbour comes } \\
\text { by, Arthur opens the door for her and greets her casually. }\end{array}$ \\
\hline 4 & $\begin{array}{l}\text { Hello, it's good to be } \\
\text { here. }\end{array}$ & $\begin{array}{l}\text { At night, in a stand-up comedy club. Arthur is gonna do } \\
\text { his stand-up in front of people. He greets them before he } \\
\text { starts his comedy. }\end{array}$ \\
\hline 5 & $\begin{array}{l}\text { Hi, what's your } \\
\text { name? }\end{array}$ & $\begin{array}{l}\text { In front of the gate of Mayor's mansion. Arthur meets the } \\
\text { Mayor's son and he greets the boy politely. }\end{array}$ \\
\hline 6 & Oh hi, guys & $\begin{array}{l}\text { At Arthur's apartment. Arthur's friends comes to see him } \\
\text { and he greets his friends casually. }\end{array}$ \\
\hline 7 & Good night & $\begin{array}{l}\text { At night, in the talk show studio. Arthur greets the } \\
\text { audience for the closing of the show. }\end{array}$ \\
\hline
\end{tabular}

\begin{tabular}{ll}
\hline $\mathbf{N}$ & Agreeing Utterances \\
$\mathbf{0}$ & \\
\hline $\mathbf{1}$ & She does
\end{tabular}

Table 3. Agreeing

\begin{tabular}{|c|c|c|}
\hline 1 & She does & $\begin{array}{l}\text { In a TV show studio. Arthur seriously tells the host that he } \\
\text { takes care of his mother. Then, the host thinks that Arthur's } \\
\text { mother must love him much and Arthur agrees with the } \\
\text { statement. }\end{array}$ \\
\hline 2 & $\begin{array}{l}\text { That's right Murray. } \\
\text { I'm not political }\end{array}$ & $\begin{array}{l}\text { At night, on the talk show. Murray asks Arthur about his look } \\
\text { to make sure that it is not a political symbol and Arthur agrees } \\
\text { with him. He speaks casually. }\end{array}$ \\
\hline 3 & $\begin{array}{l}\text { Yeah, that sounds } \\
\text { great }\end{array}$ & $\begin{array}{l}\text { At Arthur's apartment. Arthur is talking to a lady on the } \\
\text { phone. She invites Arthur to meet Murray Franklin on the TV } \\
\text { show and he agrees to be on the show. }\end{array}$ \\
\hline 4 & $\begin{array}{l}\text { I do and I'm tired of } \\
\text { pretending it's not }\end{array}$ & $\begin{array}{l}\text { At night, on the talk show. the host asks Arthur about killing } \\
\text { street guys is funny to him and Arthur agrees with the host's } \\
\text { statement. He speaks seriously. }\end{array}$ \\
\hline 5 & I know & $\begin{array}{l}\text { On the talk show studio. The host says that what has happened } \\
\text { in the town is because of Arthur. Arthur agrees with him. He } \\
\text { speaks casually. }\end{array}$ \\
\hline 6 & $\begin{array}{l}\text { I know, isn't it } \\
\text { beautiful? }\end{array}$ & $\begin{array}{l}\text { In a police car, on the way to police station. Arthur is laughing } \\
\text { to see people doing protest on the sreet. Then, the police says } \\
\text { that it is all happened because of him. Arthur agrees with the } \\
\text { statement. }\end{array}$ \\
\hline
\end{tabular}

Table 4. Thanking

\begin{tabular}{lll}
\hline $\begin{array}{l}\text { N } \\
\mathbf{0}\end{array}$ & $\begin{array}{l}\text { Thanking } \\
\text { Utterances }\end{array}$ & \multicolumn{1}{c}{ The Context of Expressive Speech Acts } \\
\hline $\mathbf{1}$ & Thanks, Murray. & $\begin{array}{l}\text { At night, in a TV show studio, when the host gives a } \\
\text { compliment to Arthur, he feels happy. Then, Arthur thanks } \\
\text { him. }\end{array}$ \\
$\mathbf{2}$ & $\begin{array}{l}\text { Thank you, Randall. } \\
\text { Thank you so much. }\end{array}$ & $\begin{array}{l}\text { In Arthur's apartment. When Randall shows his care for } \\
\text { Arthur, he thanks Randall. They speak casually. }\end{array}$ \\
$\mathbf{3}$ & Thank you, Murray & $\begin{array}{l}\text { In the backstage of TV show studio. Arthur meets Murray } \\
\text { who is the host of the show and he thanks him for inviting } \\
\text { him to the show. }\end{array}$ \\
\hline
\end{tabular}




\begin{tabular}{lll}
\hline 4 Thanks, Murray & $\begin{array}{l}\text { In the backstage of TV show studio. Murray tells some rules } \\
\text { of the show to Arthur and he lets Arthur to be on his show. } \\
\text { Then, Arthur thanks him. }\end{array}$ \\
& $\begin{array}{l}\text { In the backstage of TV show studio. Murray gives a } \\
\text { compliment about Arthur's stage name as joker. Then, Arthur } \\
\text { feels happy and thanks him. }\end{array}$ \\
\hline
\end{tabular}

\begin{tabular}{|c|c|c|}
\hline \multicolumn{3}{|c|}{ Table 5. Apologizing } \\
\hline $\begin{array}{l}\mathbf{N} \\
\mathbf{0}\end{array}$ & Apologizing Utterances & The Context of Expressive Speech Acts \\
\hline 1 & $\begin{array}{l}\text { I'm sorry, I have a } \\
\text { condition... }\end{array}$ & $\begin{array}{l}\text { In the afternoon, on the bus Arthur cannot control his } \\
\text { laughing disorder and a woman seats in front of him } \\
\text { feeling annoyed. Then, Arthur askes for an apology while } \\
\text { he is trying to not laugh. }\end{array}$ \\
\hline 2 & $\begin{array}{l}\text { Yes. I'm sorry, I just } \\
\text { showed up }\end{array}$ & $\begin{array}{l}\text { In a toilet. Arthur meets the Mayor of the city. He asks for } \\
\text { an apology for showing up to the Mayor's mansion. He } \\
\text { speaks to the Mayor politely. }\end{array}$ \\
\hline 3 & Sorry, Gary & $\begin{array}{l}\text { In Arthur's apartment. Gary wants to leave but the door is } \\
\text { locked. Arthur forgets about the lock and he says sorry to } \\
\text { Gary. }\end{array}$ \\
\hline 4 & $\begin{array}{l}\text { Okay, I'm... yeah I'm } \\
\text { sorry }\end{array}$ & $\begin{array}{l}\text { On the TV show. Arthur tells a joke which is not allowed. } \\
\text { Then, he feels regretful and asks for an apology. }\end{array}$ \\
\hline \multicolumn{3}{|c|}{ Table 6. Wishing } \\
\hline $\begin{array}{l}\mathbf{N} \\
\mathbf{0}\end{array}$ & Wishing Utterances & The Context of Expressive Speech Acts \\
\hline 1 & $\begin{array}{l}\text { I just don't want to feel so } \\
\text { bad anymore }\end{array}$ & $\begin{array}{l}\text { In the depatment of health office, Arthur talks to his } \\
\text { theraphist and asks her if she can get the doctor to increase } \\
\text { his medications because Arthur wishes to not feel bad } \\
\text { anymore. He speaks casually. }\end{array}$ \\
\hline 2 & $\begin{array}{l}\text { I should've left them } \\
\text { alone. }\end{array}$ & $\begin{array}{l}\text { In a costum room, Randall asks Arthur about his condition } \\
\text { after he got beaten by some kids. Then, Arthur casually } \\
\text { wishes that he should have left them so he did not get } \\
\text { beaten. }\end{array}$ \\
\hline 3 & $\begin{array}{l}\text { Maybe a little bit of } \\
\text { warmth, maybe a hug, } \\
\text { dad! How much as a little } \\
\text { bit of decency?" }\end{array}$ & $\begin{array}{l}\text { In a toilet. Arthur is talking to mayor of the city. Arthur } \\
\text { thinks that the mayor is his biological father. Then, he says } \\
\text { his wishes to the Mayor emotionally. }\end{array}$ \\
\hline
\end{tabular}

\section{Table 7. Exclamation}

\begin{tabular}{lll}
\hline $\begin{array}{l}\text { N } \\
\mathbf{0}\end{array}$ & Exclamation Utterances & \multicolumn{1}{c}{ The Context of Expressive Speech Acts } \\
\hline $\mathbf{1}$ & Oh no! & $\begin{array}{l}\text { At a hospital. Arthur is watching a TV show and he is } \\
\text { suprised to see a clip of himself doing a stand-up comedy } \\
\text { on the television. }\end{array}$ \\
$\mathbf{2}$ & Murray! & $\begin{array}{l}\text { In the backstage of the TV show. When Murray Franklin } \\
\text { shows up, Arthur is surprised that he finally can meet him. }\end{array}$ \\
\hline
\end{tabular}

Furthermore, the researcher also discussed the context of expressive speech acts. Based on the results, for setting, there were several places when the main character had a conversation such as in a studio, Arthur's apartment, comedy club, health department office, talent agency office, hospital, the Mayor's mansion, bus, police car, toilet, and custome room. For participants, Arthur talks to some people as the participants of the movie. There are Arthur's boss, Murray Franklin as the host, 
Randall as Arthur's friend, Gary as Arthur's friend, the woman on the bus, the lady on the phone, Thomas Wayne as the Mayor, Arthur's neighbour, the policeman, and the therapist.

Moreover, for End or purpose, it depended on each type of expressive speech acts. Each type of expressive speech acts has a certain purpose. For example, an expression of greeting was used to express salutation in a meeting. Expression of apologizing was used to express the feeling of regret for what the main character did wrong. Then, an expression of wishing was used to express the main character's desire towards something that he wanted to be true. Expression of exclamation was used to show the main character's sudden emotion when he felt surprised. The expression of thanking was used to express the main character's gratitude to someone who has done something for him. The last, the expression of agreeing was used to express the main character's approval towards an idea or a statement.

For the key or tone, Arthur mostly speaks in a casual way or informal. When Arthur performs greeting and agreeing expressions, he speaks casually. In the scene when Arthur performs apologizing expressions, he speaks regretfully. Then, when Arthur performs thanking expressions, he speaks gratefully and happily. The last, when Arthur performs wishing expressions, he speaks a little bit emotionally. Moreover, for the instrument, Arthur mostly talks face to face or orally in the movie. In a certain scene, he talks to a lady via telephone.

For the genre, it depends on the types of expressive speech acts. For example, when the main character performs expressive speech acts of greeting, the genre is about expressing greeting in a conversation. When the main character performs expressive speech acts of apologizing, the genre is about expressing an apology. When the main character performs expressive speech acts of wishing, the genre is about expressing wishes. Then, when the character expresses expressive speech acts of thanking, the genre is about expressing gratitude. The last, when the character performs expressive speech acts of agreeing, the genre is about expressing approval or agreement.

Based on the results, the act of sequence and norms were found in different events when the main character interacts with other participants. For example, the main character does something wrong that he is not supposed to do, this occurs the expressive speech act of apologizing. Then, when someone does a favour for the main character, it leads to the expressive speech act of thanking. When someone approaches the main character, it leads to the expressive speech act of greeting. On the occasion where the main character wants to change something that has happened or he wants something to be true, it can lead to an expressive speech act of wishing. When the main character gives an approval towards an idea or a statement, it leads to the expressive speech act of agreeing. The last, when the character shows sudden emotions or he feels surprised, it can lead to an expressive speech act of exclamation. It can be concluded that every type of expressive speech acts has different norms and act of sequence.

Furthermore, the researcher found that Arthur tends to use an expressive speech act of greeting more than other types of expressive speech acts because he wants to express his salutation when he recognizes or meets someone. It can be seen from the movie when Arthur meets several people and he likes to greet them. This is in line with a research by Gusti Rahayu Mulik (2018). She found that expressive speech acts of greeting and condoling were the most frequently used in her research. She said that the expression of greeting implies friendly welcome when the main character is pleased to meet someone. Next research is from Agnesi Dianti (2019). In her research, the expressive speech act of greeting is also included as the most frequently used. She said that the main character likely greeted and welcomed people when they met in the movie. The last research is from Syahidatul (2020). In his research, expressive speech acts of greeting and thanking were the most frequently used. He said that the main character likes to greet someone and show his salutation as he met some people for the first time in the movie.

Moreover, Arthur also uses the expressive speech act of agreeing more often than other speech acts because he wants to express his approval towards an idea or a statement while he is having a conversation. Arthur also uses the expressive speech act of thanking because he wants to express his gratitude or appreciation to someone 
who has done something for him. Then, Arthur uses the expressive speech act of wishing to express his strong desire towards something that he wants to be true and real. The last, Arthur uses an expression of exclamation to express his sudden emotion when he feels surprised. From all the types of expressive speech acts found in Joker movie, it can be concluded that the types of expressive speech acts can explain Arthur's situation and condition while he is speaking or having a conversation.

\section{CONCLUSIONS AND RECOMMENDATION}

According to the results, the researcher concluded that there are six types of expressive speech acts performed by the main character in Joker movie covering greeting, apologizing, thanking, wishing, agreeing and exclamation. The total data that has been analyzed by the researcher is 27 utterances indicated as expressive speech acts. They are 7 utterances of greeting, 4 utterances of apologizing, 3 utterances of wishing, 5 utterances of thanking, 6 utterances of agreeing and 2 utterances of exclamation,. From all the data, the expressive speech act of greeting is the most frequently used by the main character. It means that the main character likes to express his salutation when he meets someone.

Then, related to the research findings of the second problem, the researcher found the context of the utterances which were produced by the main character. The researcher used the theory from Dell Hyme's SPEAKING model. From the results, the researcher could conclude that the purposes of Arthur as the main character using expressive speech acts are various according to what types of expressive speech acts he produces while he is having a conversation. The researcher found that Arthur tends to use an expressive speech act of greeting more than other speech acts because he wants to express his salutation when he recognizes or meets someone.

Moreover, Arthur also uses the expressive speech act of agreeing more often than other speech acts because he wants to express his approval towards an idea or a statement while he is having a conversation. Arthur also uses the expressive speech act of thanking because he wants to express his gratitude or appreciation to someone who has done something for him. Furthermore, Arthur uses the expressive speech act of wishing to express his strong desire towards something that he wants to be true and real. The last, Arthur uses an expression of exclamation to express his sudden emotion when he feels surprised. From all the types of expressive speech acts found in Joker movie, it can be concluded that the types of expressive speech acts can explain Arthur's situation and condition while he is speaking or having a conversation.

The researcher would like to give some recommendations to the readers and the next researchers. Firstly, the researcher hopes that this research would give a contribution to the readers as information sources in understanding speech acts. Then, the researcher hopes that this research can be an additional reference for other researchers who are interested in learning more about speech acts and also in making further research on similar topics. The researcher suggests that the next researchers can discover different types of expressive speech acts which the researcher cannot find. Then, the next researchers can apply different kinds of the objects or another title of movie for developing the further research. They can also conduct further research with various kinds of data sources that can be analyzed such as novels, talk shows, drama, and speech.

\section{DAFTAR PUSTAKA}

Austin. (1962). How to Do Things with Words. Cambridge: Harvard University Press.

Agnesi, D. (2019). Expressive Speech Acts in The Drowning of Van Der Wijck Movie. Pesona Jurnal: Kajian Bahasa dan Sastra, $5(2), 62-72$.

Aristidou, A. (2015). Emotion analysis and classification: understanding the performers' emotions using the LMA entities. Computer Graphics Forum Journal, 34(6), 49-58.

Guiraud, N., Longin, D., Lorini, E., Pesty, S., \& Rivière, J.(2011). The face of emotions: a logical formalization of expressive speech acts. Richland, SC: International Foundation for Autonomous Agents and Multiagent Systems. 
Gusti, R, M. (2020). Expressive Speech Acts in Up in the Air Movie. Transformative Education and Educational Leadership Journal (AISTEEL), 214-217.

Hymes, D. (1974). Foundations of Sociolinguistics: Ethnographic Approach. Philadelphia: University of Pennsylvania Press.

Lindquist. (2015). The Role of language in emotion: Predictions from psychological constructionism. Frontiers in Psychological Journal, 6(4), 20-35.

Macagno, F. (2010). What we hide in words: Emotive words and persuasive definitions. Journal of Pragmatics, 42(7), 1997-2013.

Martinez, A. (2010). Speech Act Performance: Theoretical, empirical and methodological issues. Amsterdam: John Benjamins Publishing Company.

Norrick, N. (1978). Expressive Illocutionary Acts. Journal of Pragmatics, 2(3), 277-291. DOI: 10.1016/0378-2166(78)90005-X

Patton, M. (2002). A Guide to Using Qualitative Research Methodology. United Kingdom: Medecine Sans Frontiner (MSF).

Reisha, N. (2018). A pragmatic analysis of expressive speech acts in the movie venom. Vision: Journal for Language and Foreign Language Learning, 13(8).

Ronan, P. (2015). Categorizing expressive speech acts in the Pragmatically. Icame Journal, 39.

Rusiana. (2018). An analysis of speech act used in London has fallen movie. Vision: Journal for Language and Foreign Language Learning, $\quad 7(2), \quad 160-169$. DOI: $10.21580 / \mathrm{vjv} 7 \mathrm{i} 23022$

Searle, J. R. (1969). Speech Acts. Cambridge: Cambridge University Press.

Searle, J. R. (1979). Expression and Meaning: Studies in the theory of speech acts. Cambridge: Cambridge University Press.

Sudaryanto. (1983). Metode dan Aneka Teknik Analisis Bahasa: Pengantar Penelitian Wahana Kehidupan Secara Linguistik. Yogyakarta: Duta Wacana University Press.

Syahidatul, H. (2016). An Analysis of the Expressive Speech Acts in Crazy Rich
Asians Movie. Journal of English Language Teaching and Linguistics (JELTL), 11(1), 95-120.

Weigand, E. (2010). Dialogue: The Mixed Game. Amsterdam: John Benjamins Publishing. 